\title{
Fermentasi Bekatul Sebagai Pakan Alternatif Ayam Kampung di Yayasan Seraphine Sleman Yogyakarta
}

\author{
Yunianta $^{\# 1}$, Dwi Kusmanto ${ }^{* 2}$, Citravia Agustin*3 \\ \#Prodi Agribisnis Universitas Sarjanawiyata Tamansiswa Yogyakarta \\ 1email yunianta_yunianta@yahoo.co.id \\ *Prodi Budidaya Ternak, Akademi Peternakan Brahmaputra Yogyakarta \\ 2 email dwikusmanto719@gmail.com \\ ${ }^{3}$ email citravia08@gmail.com
}

\begin{abstract}
Abstrak-Kendala dalam usaha ayam Kampung Unggul Balitnak (KUB) skala kecil/mikro, terutama harga pakan yang mahal, untuk itu diperlukan pakan alternatif yang lebih murah tetapi mempunyai nutrisi yang baik. Salah satunya adalah pemanfaatan teknologi fermentasi pada bekatul. Metode ini telah didemonstrasikan dalam pendampingan kelompok petani, binaan Yayasan Seraphine di Pakem Sleman Yogyakarta, melalui kandang percontohan/demplot ayam KUB. Pelaksanaan pendampingan dilakukan selama 3 bulan yaitu bulan Mei hingga Juli 2021. Metode pendampingan kelompok meliputi penyuluhan dan praktek pembuatan bekatul fermentasi serta bimbingan pemeliharaan ayam dalam kandang percontohan milik yayasan. Dalam kegiatan ini digunakan ayam KUB pullet sebanyak 100 ekor. Pemeliharaan dimulai dari umur 12 minggu hingga awal bertelur. Pada minggu ke 24 ayam mulai bertelur dengan bobot ayam rata-rata 1.420 g. Pada dua minggu pertama, produksi mencapai $12 \%$, dengan berat telur rata-rata mencapai 32 g/butir, konsumsi pakan mencapai 98 g/ekor. Hal ini menunjukkan pertumbuhan yang normal. Selama 14 minggu pemeliharaan menghabiskan pakan $7,84 \mathrm{~kg}$, dan penekanan biaya Rp 10.976/ekor atau Rp 1.400/kg pakan. Dari demplot ini disimpulkan bekatul fermentasi dapat menurunkan biaya pakan tetapi terjadi penundaan bertelur hingga 2 minggu, dengan demikian bekatul fermentas dapat dijadikan alternatif untuk menekan biaya pada budidaya ayam KUB skala kecil.
\end{abstract}

Kata kunci : demonstrasi 1, ayam KUB 2, bekatul fermentasi 3 , pakan alternatif 4 .

Abstract-The constraint of small business Kampung Unggul Research Agency (KUB Chicken) is higher feed prices, the alternative feed is needed that cheaper but high nutrition content. One of them is fermentation technology of rice bran. This method was demonstrated at farmer groups assisted by Yayasan Seraphine in Pakem Sleman Yogyakarta, with demonstration plot. The mentoring was carried out for 3 months, from May to July 2021. The accompaniment method group assistance was counseling and practice to make rice bran fermentation along guidance of raised KUB Chicken in Yayasan Seraphine Sleman's demonstrated cage. In this practice, are used 100 pullet of KUB chickens. The maintenance is starts from the 12-week-old pullet until laying. The chicken start to laying egg at $24^{\text {th }}$ week, with weight average around $1.420 \mathrm{~g}$. The first two weeks, production was reached $12 \%$, with average egg weight of $32 \mathrm{~g} / \mathrm{egg}$, feed consumption reaching $98 \mathrm{~g} / \mathrm{chicken}$. This indicated for normal growth. During 14 weeks of maintenance, necessary feed is $7.84 \mathrm{~kg}$, and cost reduction was $R p$. 10.976/chicken or $R p$. $1.400 / \mathrm{kg}$. Based on the demonstration plot, it can be concluded that rice bran fermentation can reduce of cost production, but it can lay egg delayed for up to 2 weeks, so it can be an alternative feed to reduce production cost of small business KUB chicken.

Keywords: demonstrated 1, KUB chicken 2, rice bran fermentation 3, alternative feed 4 .

\section{Pendahuluan}

Pertanian merupakan sektor yang paling banyak dilakukan masyarakat di Indonesia sebagai matapencaharian, petani kebanyakan melakukan usaha tani bersekala kecil/mikro. Usaha mikro dalam sektor pertanian tidak hanya dikarenakan modal yang terbatas, tetapi biasanya juga dilakukan oleh masyarakat yang berpendidikan rendah sehingga upaya pendampingan untuk pengembangannya tidak mudah. Yayasan Seraphine yang didirikan oleh suster-suster dan tokoh masyarakat di Sleman, Yogyakarta menyadari keterbatasan masyarakat petani kecil ini dengan membuat demonstrasi plot (demplot) peternakan, antara lain ternak sapi perah untuk menghasilkan susu murni, susu pasteurisasi dan yoghurt. Kini menggembangkan demplot peternakan ayam, 
bekerjasama dengan tim pengabdian masyararakat Universitas Sarjanawiyata Tamansiswa, khususnya Fakultas Pertanian dan Akademi Peternakan Brahmaputra. Dari demplot ayam Kampung Unggul Balitnak (ayam KUB) ini diharapkan transfer teknologi mudah dijalankan, sekaligus memberi gambaran nyata usaha peternakan dan cara pengelolaannya yang ekonomis.

Ayam KUB merupakan ayam kampung asli inovasi dari Badan Litbang Pertanian hasil diseleksi selama 6 generasi. Ayam KUB dapat digunakan sebagai sumber bibit parent stock untuk penyediaan Day Old Chicken (DOC/bibit ayam) ayam kampung potong dan petelur yang dibutuhkan masyarakat untuk memenuhi kebutuhan daging dan telur ayam kampung. Ayam KUB saat ini umumnya dipelihara dengan tujuan sebagai penghasil telur tetas, telur konsumsi dan produksi daging [1]. Usaha ayam ini relatif mudah pemeliharaannya dengan teknologi yang sederhana dan sewaktu-waktu dapat dijual jika ada keperluan rumah tangga yang mendesak. Ayam KUB mempunyai prospek menjanjikan secara ekonomi, karena dapat memenuhi kebutuhan bahan pangan bergizi tinggi dan mempunyai daya serap pasar lokal maupun regional. Produktivitas ayam KUB yang dipelihara di Desa Teluk Cati, Kabupaten Hulu Sungai Utara, Kalimantan Selatan menunjukkan rata-rata produksi telur $(65-67 \%)$, berat telur $(36,16-38,12 \mathrm{~g} / \mathrm{butir})$ [2]. Produktivitas dan efisiensi usaha beternak ayam KUB perlu didukung oleh teknologi yaitu perbaikan kualitas dan kuantitas pakan, pakan yang digunakan harus murah, mudah didapatkan dan berkualitas baik salah satunya adalah bekatul.

Bekatul padi (rice bran) merupakan salah satu bahan baku untuk pembuatan ransum ternak khususnya sebagai sumber energi. Bekatul adalah hasil samping penggilingan padi dan telah banyak digunakan sebagai pakan unggas [3]. Penggunaan bekatul pada unggas sangat terbatas dikarenakan kandungan serat kasarnya yang tinggi. Selain dikarenakan kandungan serat kasarnya yang tinggi, juga dikarenakan kandungan PK (Protein Kasar) bekatul yang rendah dan adanya anti nutrisi yaitu phytat yang menyebabkan terbatasnya penggunaan $\mathrm{P}$ dan $\mathrm{Ca}$ dalam bekatul sehingga harus dibatasi [4]. Pembatasan penggunaan bekatul pada pakan ternak unggas akan berpengaruh pada biaya pakan. Bekatul merupakan bahan yang murah dan mudah ditemukan, akan tetapi penggunaanya terbatas.

Biaya pakan merupakan biaya terbesar dalam usaha peternakan, yaitu mencapai $60-70 \%$ dari seluruh biaya produksi [5]. Oleh karena itu, perlu dicari alternatif untuk menekan biaya pakan tersebut salah satunya dengan bekatul fermentasi. Fermentasi merupakan proses pemecahan senyawa organik menjadi senyawa sederhana dengan melibatkan mikroorganisme. Tujuan fermentasi adalah untuk meningkatkan kandungan nutrisi suatu produk sehingga menjadi lebih baik. Selain itu fermentasi dapat meningkatkan daya cerna dan menurunkan zat anti nutrisi.

\section{MATERI DAN METODE}

a. Materi Penyuluhan

Penyuluhan dan demonstrasi plot (demplot) ini dilakukan pada kelompok petani binaan Yayasan Seraphine di Pakem Sleman, Yogyakarta menggunakan ayam KUB pullet sebanyak 100 ekor dengan kandang percontohan terbuat dari bambu beralaskan litter, dengan bahan dari sekam. Ukuran kendang $3 \times 5 \mathrm{~m}^{2}$, berdinding anyaman bambu.

Pakan ayam menggunakan pakan jadi dan dicampur bekatul yang telah difermentasi dengan perbandingan $1: 1$, dengan perhitungan harga, $\mathrm{Rp} 6.000,-/ \mathrm{kg}$, atau penghematan $\mathrm{Rp} 1.400,-/ \mathrm{kg}$ dibanding pakan komersial.

\section{b. Metode Penyuluhan}

Sebagai percontohan dan demonstrasi selama penyuluhan dan pemeliharaan, digunakan metode demplot. Pelaksanaan pendampingan yang dilakukan selama 3 bulan yaitu, bulan Mei hingga Juli 2021 bersama tim pengabdi. Kegiatan pendampingan kelompok meliputi penyuluhan dan praktek pembuatan bekatul fermentasi serta bimbingan pemeliharaan ayam dalam kandang percontohan milik yayasan.

\section{HASIL DAN PEMBAHASAN}

a. Pelaksanaan Penyuluhan

Pelaksanaan penyuluhan dilaksanakan pada bulan Mei hingga Juli 2021, diawali dari observasi kebutuhan kelompok dan motivasi untuk belajar serta mengembangkan peternakan ayam KUB. Penyuluhan dihadiri 26 orang yang terdiri dari petani dan pengurus yayasan. Usaha ayam KUB sudah lama diinginkan oleh peternak, setelah 2 tahun mengembangkan peternakan sapi perah dan pengolahan hasil susu, berupa susu pasteurisasi dan susu segar. Dengan demikian petani sudah terbiasa untuk beternak dan didukung lahan serta iklim di Kecamatan Pakem yang sejuk, karena berketinggian $700 \mathrm{~m}$ dari permukaan laut.

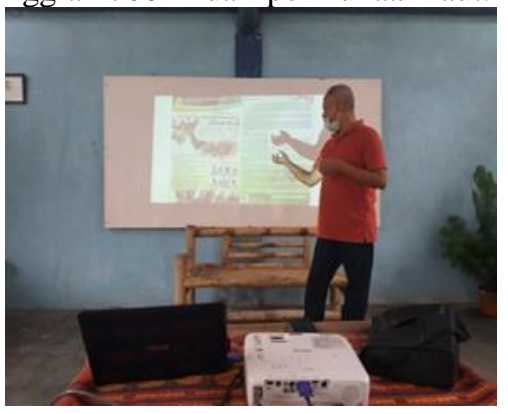

Gambar 1. Saat penyuluhan Ayam KUB 
Penyuluhan yang dilakukan meliputi aspek budidaya ayam KUB, yang terdiri dari aspek bibit, pakan, perkandangan, pengendalian penyakit, tatacara pemeliharaan dan aspek pemasaran. Pembuatan pakan alternatif dengan bahan limbah pertanian yaitu bekatul yang difermentasi. Fermentasi bekatul dilakukan dengan memberikan bakteri sebagai bio starter (Lactobacillus Sp.) dengan merk komersial EM4. Fermentasi menggunakan tempat dari tong plastik dan diperam selama minimal 1 minggu, baru dicampurkan pada pakan ayam komersial, dengan perbandingan antara pakan komersial dan pakan alternatif bekatul fermentasi $1: 1$. Penambahan asam amino metionin dan lisin diberikan sebanyak 0,2 dan $0,4 \%$ dari campuran pakan utama, serta vitamin $1 \%$, yang terdiri atas campuran vitamin dan mineral.

Bekatul merupakan limbah hasil penggilingan padi, sudah lama digunakan sebagai pakan ternak. Jumlah penggunaan bekatul dalam pakan unggas terbatas. Kandungan nutrisi yang terdapat di bekatul yang berkualitas baik antara lain protein kasar $9-12 \%$, pati $15-35 \%$,lemak $8-12 \%$, dan serat kasar $8-11 \%$ [6]. Diketahui kandungan serat kasar bekatul lebih tinggi dari pada jagung atau sumber energi yang lain, oleh karena itu bekatul diberikan dalam jumlah yang terbatas tergantung pada jenis ternaknya. Komponen utama dari bekatul adalah karbohidrat yaitu sekitar $40-49 \%$, karena bekatul tersusun dari endosperm.

Selanjutnya dilaporkan bahwa ditinjau dari komposisinya, bekatul merupakan bahan pakan yang mempunyai nilai kalori tinggi, dengan monosakarida penyusun karbohidrat berupa glukosa, galaktosa, fruktosa dan xylosa [7]. Bekatul mudah tengik dan memiliki ikatan asam lemak tidak jenuh. Terbatasnya penggunaan bekatul dalam pakan unggas selain dikarenakan kandungan serat kasarnya yang tinggi juga dikarenakan kandungan Protein Kasar bekatul yang rendah dan adanya anti nutrisi yaitu phytat yang menyebabkan terbatasnya penggunaan $\mathrm{P}$ dan Ca dalam bekatul [4]. Asam phytat merupakan zat anti nutrisi yang mampu berikatan dengan protein dan mineral seperti $\mathrm{Ca}, \mathrm{P}, \mathrm{Fe}, \mathrm{Zn}$, dan $\mathrm{Mg}$. Asam phytat di bekatul sulit larut di air dan tahan panas, sebab itu bekatul sulit dicerna [8].

Cara untuk meningkatkan nilai nutrisi dan kecernaan bekatul serta aman penggunaannya adalah dengan cara biologis yaitu dengan teknik fermentasi [9]. Peningkatan yang terjadi pada bekatul fermentasi adalah meningkatnya kandungan protein kasar. Fermentasi merupakan salah satu teknologi pengolahan bahan pakan secara biologis yang melibatkan aktifitas mikroorganisme guna memperbaiki gizi bahan berkualitas rendah. Biasanya bahan produk fermentasi relatif bisa bertahan lama. Fermentasi dapat meningkatkan kualitas nutrisi bahan pakan, karena proses fermentasi terjadi perubahan kimiawi senyawa-senyawa organik (karbohidrat, lemak, protein, serat kasar dan bahan organik lain baik dalam keadaan aerob maupun anaerob, melalui kerja enzim yang dihasilkan mikroba.

Proses fermentasi dapat meminimalkan pengaruh antinutrisi dan meningkatkan kecernaan bahan pakan dengan kandungan serat kasar tinggi yang terdapat pada bekatul [10]. Metode fermentasi yang dapat digunakan untuk menurunkan serat kasar pada bekatul adalah fermentasi dengan menggunakan probiotik cair EM4 yang mengandung sebagian besar bakteri fotosintetik (Rhodopseudomonas sp), bakteri asam laktat (Lactobacillus $s p$ ), yeast (Saccharomyces $s p$ ) yang menguntungkan bagi pertumbuhan produksi ternak. Lebih lanjut dijelaskan bahwa bekatul fermentasi dapat diberikan pada ayam hingga, 70\%. [11][12] Pada ayam KUB Bekatul fermentasi dapat menghasilkan konversi pakan, menjadi 3,2, dan tingkat keuntungan hingga Rp 3.400/ekor selama pemeliharaan 10 minggu dan mencapai bobot badan ratarata $0,9 \mathrm{~kg}$. Dalam pelaksanakan pengabdian ini menggunakan perbandingan bekatul fermentasi dan pakan komersial BR1 Comfeed (1:1) dan penambahan vitamin dan mineral.

\section{b. Pembuatan Pakan Bekatul Fermentasi}

Dalam pengabdian ini berhasil membuat pakan bekatul fermentasi sebanyak $200 \mathrm{~kg}$, pembuatan bekatul fermentasi dilakukan oleh peserta penyuluhan dan bersama mahasiswa APB. Bekatul fermentasi yang baik diindikasikan dengan warna kecoklatan, aroma harum, tidak berjamur, kadar air turun, tekstur tidak menggumpal, serta disukai ternak.

Bekatul padi adalah hasil samping penggilingan padi dan telah banyak digunakan sebagai pakan ternak. Bekatul padi didapat dari hasil samping pemisahan beras dengan sekam (kulit gabah) pada gabah yang telah dikeringkan melalui proses pemisahan dengan ditumbuk atau digiling yang dapat digunakan sebagai pakan ternak. Proses pemisahan menjadi bekatul ini akan mendapatkan sekitar $10 \%$ bekatul padi, $50 \%$ beras dan sisanya hasil ikutan seperti pecahan butir beras, sekam dan sebagainya, akan tetapi persentase ini tergantung pada umur dan jenis padi itu sendiri, banyak faktor yang mempengaruhinya. Bekatul padi atau yang sering kita kenal sebagai bekatul atau dalam bahasa inggris disebut rice brand, merupakan salah satu bahan baku untuk pembuatan ransum ternak khususnya sebagai sumber energi. Sebenarnya bekatul padi yang terdapat dipsaran itu ada 2 jenis, yaitu bekatul padi kasar dan bekatul padi halus atau yang disebut dengan bekatul. Kandungan nutrisi dari 2 jenis bekatul ini berbeda, kandungan proteinnya lebih tinggi pada bekatul padi halus [3]. Harga jualnya pun juga berbeda, di tempat penjualan pakan

Bekatul padi sebagai sumber bahan pakan sumber energi mengandung serat kasar yang cukup tinggi 11,4\%, kandungan protein kasar sekitar $12,9 \%$, lemak $13 \%$ dan 
mengandung senyawa anti nutrisi fitat. Ketersediaan bekatul padi sepanjang tahun berfluktuasi. Kondisi ini disebabkan karena bekatul padi pada musim panen ketersediaanya melimpah, sebaliknya pada musim kemarau berkurang akibat petani banyak yang menanam palawija. Selain itu bekatul padi tidak dapat disimpan pada jangka waktu yang lama. Hal ini disebabkan karena ketidakstabilan bekatul padi selama penyimpanan. Suatu teknologi penyimpanan bekatul padi dengan cara fermentasi dapat memperlama masa simpan dan meningkatkan kandungan gizi bekatul padi.

Teknologi bekatul padi fermentasi dapat memperpanjang waktu simpan bekatul padi dan menurunkan kandungan asam fitat yang ada pada bekatul padi sehingga penggunaannya dapat maksimal dalam ransum ternak.

Asam fitat ini mampu berikatan dengan protein, mineral, dan pati membentuk garam atau senyawa komplek, sehingga mineral, protein dan pati yang terkandung dalam ransum dapat optimal digunakan oleh ternak. Tujuan dari fermentasi ini adalah memecah kandungan serat, protein dan karbohidrat menjadi senyawa yang lebih sederhana, fermentasi bekatul padi dapat menggunakan ragi, bakteri, fungi atau kombinasi dari ketiganya pada kondisi anaerobik atau tertutup. Tujuan fermentasi adalah untuk meningkatkan kandungan nutrisi suatu produk sehingga menjadi lebih baik. Fungsi lainnya untuk menurunkan zat anti nutrisi dari bahan utama.

Hasil penyuluhan dan praktek pembuatan pakan, memberikan kesadaran untuk mencoba menggunakan bekatul fermentasi sebagai pakan ayam alternatif. Petani juga sudah dapat membuat pakan alternatif yang lebih murah dengan demikian, petani mempunyai keyakinan untuk budidaya ayam KUB yang menguntungkan. Penggunaan pakan fermentasi dalam kegiatan ini menghemat biaya pakan sebesar Rp 1.400,-/kg pakan.

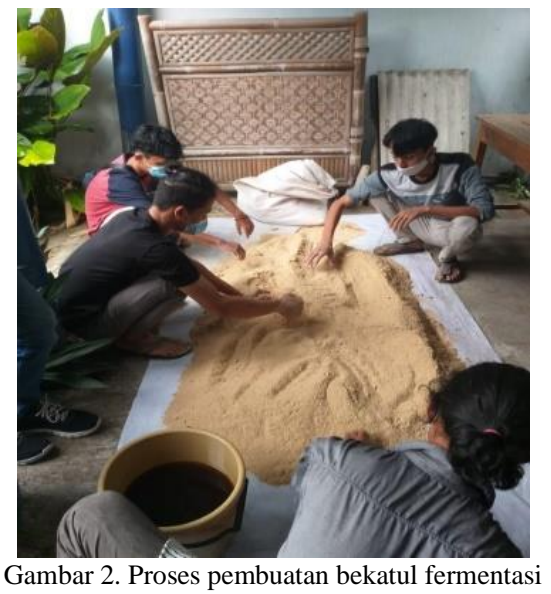

c. Budidaya Ayam KUB
Dalam pengabdian ini ayam KUB dipelihara untuk memproduksi telur tetas dan telur konsumsi, diharapkan dapat meningkatkan pendapatan petani yang lebih tinggi dari budidaya ayam kampung biasa. Melalui praktek pemeliharaan secara langsung dan pendampingan mulai memelihara pullet hingga bertelur, Pemberian pakan setiap hari sesuai standar Tabel 1, serta pencegahan penyakit dengan biosecurity yang baik dan vaksinasi ND dan Gomboro. Vaksi ND diberikan dengan Injeksi intra muskulus pada umur 12 minggu, Gumboro diberikan melalui air minum.

Peluang pengembangan ayam KUB memiliki prospek yang baik dan menguntungkan dengan pola pemeliharaan semi-intensif maupun intensif. Strategi dan upaya pengembangan untuk meningkatkan populasi, produksi, produktivitas dan efisiensi usaha beternak ayam KUB perlu didukung oleh teknologi yaitu perbaikan kualitas dan kuantitas pakan, pencegahan dan pengendalian penyakit (pemanfaatan jamu ternak dan vaksinasi ND) secara berkala dengan menjaga kebersihan atau sanitasi kandang dan lingkungannya [12].

Pemilihan ayam KUB dalam demplot ini berdasarkan pertimbangan dan saran dari Penyuluh dan Balai Penelitian dan pengembangan pertanian. Balitbangtan telah menghasilkan inovasi bibit unggul ayam kampung yang diberi nama Ayam Kampung Unggul Balitbangtan (Ayam KUB). Ayam KUB telah diperkenalkan Menteri Pertanian pada 2014 dengan nama Ayam KUB-1 melalui Keputusan Menteri Pertanian No. 274/Kpts/SR.120/02/2014. Ayam KUB merupakan ayam kampung asli yang telah diseleksi selama 6 generasi. Ayam KUB dapat digunakan sebagai sumber bibit parent stock untuk penyediaan Day Old Chicken (DOC/bibit ayam) ayam kampung potong dan petelur dibutuhkan masyarakat untuk memenuhi kebutuhan daging dan telur ayam kampung [1].

Ayam KUB memiliki keunggulan mampu bertelur lebih banyak mencapai 160-180 butir/ekor/tahun, memiliki bobot badan umur 20 minggu ( \pm 5 bulan) berkisar antara 1.200 1.600 gram, umur awal bertelur lebih awal sekitar 20-22 minggu dengan bobot telur 35-45 gram. Masa mengeram ayam yang berkurang hingga tinggal $10 \%$ sehingga ayam cepat bertelur kembali serta lebih tahan terhadap penyakit. Berikut disajikan pada Tabel 1 rata-rata konsumsi pakan dan bobot dalam demplot ayam betina $(\mathrm{g})$.

Tabel 1. Rata-rata konsumsi pakan dan bobot dalam demplot ayam betina $(\mathrm{g})$

\begin{tabular}{ccccc}
$\begin{array}{c}\text { Umur } \\
\text { (minggu) }\end{array}$ & $\begin{array}{c}\text { Bobot } \\
\text { badan } *\end{array}$ & $\begin{array}{c}\text { Konsumsi } \\
\text { pakan* }\end{array}$ & $\begin{array}{c}\text { Bobot } \\
\text { badan** }\end{array}$ & $\begin{array}{c}\text { Konsumsi } \\
\text { pakan** }\end{array}$ \\
\hline
\end{tabular}




\begin{tabular}{lcccc}
\hline 12 & 843 & 60 & 860 & 60 \\
13 & 923 & 65 & 950 & 65 \\
14 & 999 & 70 & 1.020 & 70 \\
15 & 1.058 & 75 & 1.090 & 75 \\
16 & 1.093 & 80 & 1.150 & 80 \\
17 & 1.138 & 85 & 1.170 & 85 \\
18 & 1.170 & 90 & 1.210 & 90 \\
19 & 1.200 & 95 & 1.305 & 95 \\
20 & 1.229 & 100 & 1,360 & 100 \\
21 & - & - & 1.370 & 100 \\
22 & - & - & 1.420 & 100
\end{tabular}

Sumber : *Panen ayam kampung 70 hari [13], ** Hasil pemeliharaan ayam KUB di Demplot Yayasan Seraphine.

Dari tabel 1, diatas menunjukkan bahwa budidaya yang dilakukan petani menunjukkan keberhasilan, dilihat dari bobot badan dan pakan yang diberikan sudah mencapai standar dari penelitian yang ada [12].

\section{d. Produktivitas ayam KUB}

Dalam kegiatan ini digunakan ayam pullet sebanyak 100 ekor. Pemeliharaan dimulai dari pullet berumur 12 minggu hingga mulai bertelur. Pada minggu ke 26 ayam mulai bertelur dengan bobot ayam rata, rata 1.420 g. Pada dua minggu pertama, produksi mencapai $12 \%$, dengan berat telur rata-rata mencapai $32 \mathrm{~g} /$ butir, konsumsi pakan mencapai 98 g/ekor. Hal ini menunjukkan pertumbuhan yang normal. Selama 14 minggu pemeliharaan menghabiskan pakan $7,84 \mathrm{~kg}$, dan penekanan biaya $\mathrm{Rp}$ 10.976/ekor atau $\mathrm{Rp} 1.400 / \mathrm{kg}$ pakan,

Dari demplot ini petani mendapat gambaran nyata pemanfaata bekatul fermentasi dapat menurunkan biaya pakan, pertumbuhan ayam berjalan normal, Kesehatan terjaga, karena selama pemeliharaan tidak ada ayam yang mati, ayam KUB pada umur 22 minngu mulai bertelur tetapi pada umumnya ayam kampung dan ayam KUB bertelur mulai minggu ke 20 [12] [13]. Dengan demikian terjadi penundaan waktu bertelur selama 2 binggu, hal ini dapat disebabkan karena pakan yang menggunakan bekatul fermentasi dalam pemeliharaan ini Protein kasarnaya hanya $16,5 \%$, sedangkan pada umunya kebutuhan minimal $17 \%$.

\section{KESIMPULAN}

Hasil penyuluhan dan praktek serta pembuatan demplot ayam KUB memeberikan bukti nyata kepada petani bahwa bekatul fermentasi dapat digunakan sebagai pakan ayam KUB, serta menurunkan biaya pakan tetapi terjadi penundaan bertelur hingga 2 minggu, dengan demikian bekatul fermentasi masih dapat dijadikan pakan alternatif untuk menekan biaya pada budidaya ayam KUB skala kecil.
Terima kasih atas kerjasamanya antara Universitas Sarjanawiyata Tamansiswa dengan Akademi Peternakan Brahmaputra serta Yayasan Seraphine Yogyakarta yang sudah bersedia memberikan tempat untuk pelaksanaan pengabdian masyarakat.

\section{DAFTAR PUSTAKA}

[1] H. Noferdiman, Fatati, dan Handoko. "Penerapan teknologi pakan lokal bermutu dan pembibitan ayam kampung menuju kawasan village poultry farming (VPF) di Desa Kasa Lopak Alai Kabupaten Muaro Jambi (Indonesia)". Jurnal Pengabdian Pada Masyarakat., vol. 29, pp. 60-70. 2014

[2] Suryana. "Development of KUB Chicken in South Kalimantan. Indones". Indonesia Bulletin of Animal and Veterinary Science. vol. 27 , no. 1 , p. 45.2017

[3] N. Supartini and E. Fitasari. "Penggunaan Bekatul Fermentasi Aspergillus Niger Dalam Pakan Terhadap Karakteristik Organ Dalam Ayam Pedaging". Buana Sains, vol. 11, no. 2, pp. 127-136. 2011

[4] D. Hardini. "The Nutrient Evaluation of Fermented Rice Bran as Poultry Feed". International Journal of Poultry Science . vol. 9, no. 2, pp. $152-154.2010$

[5] D. M. S. Tarigan and D. S. T. Manalu. 2019. "Fresh Azolla Pinnata as Alternative Feed to Reduce Broiler Production Cost," Jurnal Agrisep. vol. 18, no. 1, pp. 177-186, 2019.

[6] E. Prambudi. "Nutrisi Dedak". http : // article 34. Blogspot. Com /2007/03/animal - nutrition-iv- dedak.html.2007. Diakses 8 September 2021 .

[7] Sarwono. "Beternak Ayam Buras". Jakarta: Penebar Swadaya. 2006

[8] Sobri. Bekatul Fermentasi Genjot Bobot Ayam.http://www.trubusonline.co.id/mod.php? $\bmod =$ publisher\& op=viewarticle $\&$ cid=8\&artid=2039. 2006. Diakses 8 September 2021

[9] Gunawan, B. P. Widyobroto, dan A. R. Setioko. "Teknologi Pakan Mendukung Pengembangan Sapi Potong di Indonesia". ISBN: 978-., Yogyakarta: Gadjah Mada University Press.2014.

[10] Sukaryana, Y. U. Atmomarsono, V. D. Yunianto, and E. Supriyatna. "Peningkatan Nilai Kecernaan Protein Kasar Dan Lemak Kasar Produk Fermentasi Campuran Bungkil Inti Sawit Dan Dedak Padi Pada Broiler". JITP Journal. pp. 167-172. 2019.

[11] Ali, N. A. Agustina, and D. Dahniar. "Pemberian Dedak Yang Difermentasi Dengan EM4 Sebagai Pakan Ayam Broiler". Agrovital J. Ilmu Pertan., vol. 4, no. 1, p. 1. 2019.

[12] Yunianta dan A. Purnomo."Manfaat bekatul fermentasi untuk peningkatan performan dan pendapatan peternak ayam kampung KUB Yogyakarta". Akademi Peternakan Brahmaputra. 2020

[13]T. Sartika. 2016. "Panen Ayam Kampung 70 Hari". Penebar Swadaya. Jakarta.

\section{UCAPAN TERIMA KASIH}

